\title{
Countermeasures for the Development of Yiwu's Small Commodity Export Under the Background of Cross-Border E-commerce
}

\author{
Ying $\mathrm{CHEN}^{1}$, Hui-lin $\mathrm{YAO}^{2 *}$
}

\author{
${ }^{1}$ Xiamen University of Technology, Xiamen, Fujian, China \\ ${ }^{2}$ Xiamen University of Technology, Xiamen, Fujian, China \\ *Corresponding author.Email: hlyao@xmut.edu.cn
}

\begin{abstract}
With the continuous progress of Internet technology and the rapid development of global economy, Cross-border Ecommerce has emerged in the world market. Under the environment of Cross-border E-commerce, the export of small commodities in Yiwu experienced a rapid development period. In recent years, however, export growth has slowed. Many problems have been exposed in the process of commodity export. This paper analyzes the development countermeasures of Yiwu commodity export under the environment of Cross-border E-commerce, and is committed to making Yiwu commodity break through the current bottleneck under the environment of Cross-border E-commerce and realize a new leap in export development.
\end{abstract}

Keywords : Internet, Cross-border E-commerce, Yiwu small commodities

\section{INTRODUCTION}

With the advent of the "Internet plus" era, the global economic environment has changed dramatically. The traditional mode of foreign trade is changing to a rapidly rising Cross-border E-commerce. Cross-border Ecommerce are increasingly becoming a new trend in China's foreign trade development.

In 2018, the growth rate of China's Cross-border Ecommerce was much higher than that of traditional import and export trade, and the transaction scale reached 9 trillion yuan, with a year-on-year growth of $11.6 \%$. According to the relevant data, the turnover of China's Cross-border E-commerce will reach 12 trillion in 2020, with a three-year compound growth rate of $12.44 \%$. In the future, China's Cross-border E-commerce market has a huge development space [1]. In 2018, Yiwu was approved as "National Cross-border E-commerce Comprehensive Experimental Zone" as the only countylevel city. Yiwu's unique geographical location, vast Cross-border E-commerce market, rich Cross-border Ecommerce resources and strong national policy support have enabled the rapid development of Cross-border Ecommerce in Yiwu. Yiwu commodity is famous at home and abroad for its variety, good quality and low price. Small commodities cover clothing, imitation jewelry, plastic products, zippers and a series of products. In recent years, with the rapid development of the Internet, many Yiwu small commodity exporters also occupy a place in the field of Cross-border E-commerce.

\section{STATUS OF YIWU'S SMALL COMMO- DITY EXPORT}

\subsection{Transaction of Yiwu small commodities on Cross-border E-commerce platform}

\subsubsection{Yiwugou}

Yiwugou.com platform is jointly built by Dunhuang.com and Yiwu commodity group. It is the official website of Yiwu Commodity wholesale market. There are tens of millions of merchants from Yiwu small commodity market entering Yiwu shopping platform, with thousands of types of goods and nearly 3 million single products. Foreign Cross-border E-commerce buyers generally purchase in large quantities [2].

In 2016, Yiwugou's online transaction volume exceeded 6 billion yuan, and the offline transaction volume was 40 billion yuan. 2017 is the fifth anniversary of Yiwu shopping online. The online transaction amount of Yiwu small commodities has exceeded that of the real 
market, reaching 26.5 billion yuan. In 2018, the biggest sales volume on Yiwu shopping platform is Yiwu small commodities, including daily necessities, clothing and crafts. The main Cross-border E-commerce buyers are mostly from the United States, Southeast Asia and other countries and regions. 2019 is the seventh anniversary of Yiwu shopping online. As of October 21, 2019, there are more than 3 million Cross-border E-commerce buyers registered on the Yiwu shopping platform, with an average daily active buyer of nearly 100000. Cross border E-commerce buyers mainly come from Indonesia, the United States, Malaysia, Thailand, Russia, India, Africa and other countries and regions [3].

2020 is a milestone year. On November 19, 2020, Yiwu shopping platform won the "Qianfeng Potential Award" which represented the possibility of a market value of 100 billion yuan for its outstanding performance in the Cross-border E-commerce industry.

\subsubsection{Alibaba international station}

According to the data of 2019 on Alibaba.com, the online transaction volume of Yiwu commodities increased by $117 \%$ year on year, and the online transaction volume of orders below US \$5000 increased by $182 \%$ year on year. On November 27,2019 , Yiwu Commodity zone of Alibaba.com was officially launched. The establishment of Yiwu small commodity zone not only improves the certainty, stability and convenience of Cross-border trade, but also helps SMEs in Yiwu to explore new business opportunities of Cross-border Ecommerce.

\subsection{Characteristics of Yiwu's small commodity export}

\subsubsection{Export types of small commodities are} increasing, and the structure of export commodities is not perfect.

With the increase of Yiwu's total Cross-border Ecommerce exports of small commodities, the types of small commodity exports are also constantly enriched from 80000 kinds of goods in 10 categories in 2010 to about 360000 kinds of goods in 29 categories in 2017. In addition to the original clothing, plastic products and imitation accessories, the main export commodities also include handmade products and toys. From the perspective of the overall structure of Cross-border Ecommerce exports, most of Yiwu's small commodities are still labor-intensive products with labour-intensive products, small profit margin and imperfect overall structure.

\subsubsection{The main export markets of Yiwu small commodities are relatively stable.}

With the development of the Internet, the international market space for Cross-border cooperation of small commodities in Yiwu has gradually increased. At present, it has established close ties with more than 200 countries in Arab, African and other regions [4]. Yiwu small commodity Cross-border E-commerce exports to many countries, among which the United States, ASEAN, EU, South Korea, Russia account for the top five of Yiwu small commodity export markets. With the changing world economic environment, the market share of these countries or regions is also changing. On the whole, the main export markets of Yiwu small commodity Crossborder E-commerce are relatively stable and concentrated.

\section{PROBLEMS OF YIWU'S SMALL COM- MODITY EXPORT}

\subsection{Cross-border E-commerce sellers have weak awareness of building Yiwu small commodity public brand.}

Although there are many kinds of Yiwu small commodities on the Cross-border E-commerce platform, most of them do not have their own brands. Among Yiwu's small commodities, there are only a few famous brands in China, and only a dozen of them are exempt from inspection. There are few independent brands such as "Langsha" socks, "Xinguang" accessories, "Julong" bags, "Hengxiang" zippers, etc. Moreover, most of these independent brands are limited in China and are not wellknown internationally. Yiwu small commodities are lack of brand effect, which is not conducive to the sales of small commodities on the Cross-border E-commerce platform to a certain extent.

On the one hand, the weak awareness of Cross-border E-commerce sellers in building public brands is related to the low added value of Yiwu small commodities. At present, Yiwu small commodities sold on Alibaba, Amazon, Aliexpress and other large Cross-border Ecommerce platforms are mostly labor-intensive products such as clothing, jewelry, bags, zippers, plastic products, etc. The production and processing of small commodities are still at the low end of the industrial chain, with low added value. In the competition of Cross-border Ecommerce platforms, they blindly rely on low prices [5]. Yiwu commodity itself is not high in added value and competitiveness, which increases the difficulty of brand building.

On the other hand, the weak awareness of Crossborder E-commerce sellers in building Yiwu small commodity public brand is related to the lack of government publicity. The government lacks publicity on the importance of building Yiwu small commodity brand in the Cross-border E-commerce environment, and lacks 
relevant policies to encourage and support Cross-border E-commerce sellers to build public brands.

\subsection{Homogenization of Yiwu small commodities on Cross-border E-commerce platform is serious.}

First of all, the innovation of Yiwu small commodities is insufficient. Many Yiwu small commodities on the Cross-border E-commerce platform are old wine in new bottles. Except for the different colors of the small commodities, their essence and style are nothing new. Secondly, the government's protection of intellectual property rights is insufficient. Due to the insufficient protection of intellectual property rights and the lack of clear measures to combat piracy, the homogenization of small commodities on Cross-border E-commerce platforms is becoming more and more serious.

\subsection{Lack of professional Cross-border E- commerce marketing talents.}

Because the sellers on the Cross-border E-commerce platform lack the understanding of the sales mode of the E-commerce platform, they cannot fully display Yiwu small commodities on the Cross-border E-commerce platform, which reduces the attraction to Yiwu small commodities and is not conducive to the rapid growth of Yiwu small commodities' turnover on the Cross-border E-commerce platform. The lack of professional Crossborder E-commerce marketing talents will also indirectly affect Cross-border buyers' satisfaction with the transaction. Due to the lack of foreign trade and logistics knowledge of Cross-border E-commerce sellers, the delivery and after-sales needs of Cross-border buyers cannot be met in time.

There are several reasons for the lack of professional Cross-border E-commerce marketing talents in Yiwu: Firstly, other cities around Yiwu have strong comprehensive strength and strong attraction for talents. Secondly, Yiwu small commodity sellers have limited knowledge of the new sales mode and operation mode of Cross-border E-commerce. Thirdly, it takes a lot of time to find the best Cross-border E-commerce marketing mode for so many kinds of small commodities in Yiwu.

\subsection{The Cross-border logistics system is not sound enough.}

There are many ways of logistics transportation for Yiwu small commodity Cross-border E-commerce, which have their own problems. At present, the main logistics methods are postal-parcel, international commercial express, Cross-border special line logistics and overseas warehouse. These commonly used logistics modes have obvious disadvantages. With the rapid growth of Yiwu's small commodity export in the Cross- border E-commerce environment, the pressure of Crossborder logistics transportation industry is increasing. Therefore, it is urgent to find a reasonable logistics mode and improve the Cross-border E-commerce logistics system.

\section{COUNTERMEASURES OF YIWU'S SMA-LL COMMODITY EXPORT}

\subsection{Enhance the brand building awareness of Cross-border E-commerce sellers and improve the added value of Yiwu small commodities.}

Build a good industry atmosphere and encourage Yiwu small commodity sellers to establish their own brands in the Cross-border E-commerce environment. Enhancing the brand building awareness of Cross-border E-commerce sellers is inseparable from a good industry atmosphere. The government regularly conducts relevant lectures to popularize the importance of brands and patents, and to guide Cross-border E-commerce sellers to establish their own brands.

Old brand of small commodities in Yiwu which is well-known in the domestic market can enter the international market and improve its international reputation.

First of all, Cross-border E-commerce sellers should locate the international market accurately, and the goods sold on the Cross-border E-commerce platform can be more targeted at customers in Southeast Asia. Secondly, in the marketing of Cross-border E-commerce platform, Cross-border E-commerce sellers should employ experienced Cross-border E-commerce marketing team, make full use of Cross-border E-commerce platform, actively implement network brand strategy, and improve the marketing level of Yiwu small commodities. Thirdly, adjust the industrial structure, promote industrial upgrading, make horizontal and vertical development of Yiwu small commodities. Brand building is closely related to the product itself, and Cross-border Ecommerce sellers should not forget to improve the added value of small commodities when building the brand of Yiwu small commodities. Combined with its own development of Yiwu small commodities, strive to make technology become the core competitiveness, and promote the sustainable development of Yiwu small commodities.

\subsection{Realize personalized customization of small commodities through Cross-border $E$ - commerce platform to enhance the innovation of small commodities.}

In order to increase the innovation of small commodities, combined with the characteristics of Yiwu small commodities sold on the Internet platform, there are mainly the following two schemes. One is "one-to- 
one" customization, that is, buyers on the Cross-border E-commerce platform put forward specific demand such as specific color, specification, style, material, etc for goods to sellers, sellers integrate specific orders from different customers at the back end, optimize production scheduling, and use flexible production lines for personalized production. For example, Aidingge focuses on the customization of shoes. According to the specific needs of 18-35 years old young people, it carries out the customized production of shoes, and has achieved great success. The second is "one to many" customization. Cross border E-commerce sellers use big data to mine the common needs of a specific target market, and then produce according to the needs. To a certain extent, this way improves the business efficiency of the business, and makes the business more targeted for the production of small commodities.

\subsection{Cultivating professional Cross-border E- commerce marketing talents.}

Training professionals who understand both Crossborder E-commerce marketing and the characteristics of Yiwu small commodities is the key to the development of Yiwu small commodities in the Cross-border Ecommerce environment.

First of all, Yiwu small commodity sellers can explore talents from multiple channels. Yiwu small commodity sellers can carry out project cooperation with colleges and universities to cultivate Cross-border E-commerce marketing professionals. Considering the needs of sellers and combined with professional characteristics, they can train targeted talents in the form of projects in Crossborder E-commerce, Foreign trade, Logistics and other majors of colleges and universities.

Secondly, the seller can select employees internally and conduct professional training for employees through various ways, such as on-site teaching, online courses, distance education, etc. The purpose is to enable employees to basically master a series of professional skills required by Cross-border E-commerce, such as store registration, product shooting, image processing, product copywriting, product innovation and after-sales service. At the same time, encourage employees to learn foreign languages, or more professional knowledge of foreign trade logistics.

Finally, in terms of talent recruitment, in addition to school recruitment, social recruitment can also be carried out. Attract talents with superior treatment, let the talents who know the knowledge of Cross-border E-commerce enter the enterprise, let them master the relevant knowledge of Yiwu small commodities, help the small commodities operated by sellers enter the field of Crossborder E-commerce, and quickly occupy a place on the Cross-border E-commerce platform.

\subsection{Optimize logistics system and improve logistics efficiency.}

A sound logistics system is conducive to the rapid development of Yiwu small commodities in the field of Cross-border E-commerce. Cross border E-commerce sellers operating Yiwu small commodities can reasonably choose the logistics mode according to their own economic strength and the buyer's location.In the United States, which has a large export volume, the logistics mode of Co-building overseas warehouses is mostly chosen by small commodity Cross-border E-commerce sellers above average level of economic strength. These sellers with strong economic strength can also rent part of overseas warehouses to SMEs with less economic strength. For small commodity sellers with less economic strength, they can choose to cooperate with other logistics companies. This not only facilitates the storage of Yiwu small commodities overseas, maintains the quality of small commodities, but also saves the logistics cost and improves the logistics efficiency. The establishment of

Yiwu Cross-border E-commerce bonded logistics platform is a very important step in the process of optimizing the logistics system. The establishment of Yiwu Cross-border E-commerce bonded logistics platform has further improved the logistics system and brought greater convenience to the Cross-border Ecommerce transactions of small commodities. The establishment of Yiwu Cross-border bonded logistics platform makes use of the functions of "Customs Territory" storage and processing, and solves the problem of small commodity after-sales more effectively. This not only improves the quality of after-sales service, but also saves logistics costs.

\section{CONCLUSION}

As the only county-level city approved as the "National Cross-border E-commerce Comprehensive Experimental Zone", Yiwu enjoys the huge export dividend brought by Cross-border E-commerce, but also faces unprecedented challenges. Under the background of Cross-border E-commerce, the analysis of Yiwu small commodity export development strategy is of great significance. Through the joint efforts of all parties, Yiwu small commodities will get rid of the bottleneck encountered in the process of export development and find its optimal way.

\section{REFERENCES}

[1] Ma Jing. Literature review and current situation analysis of China's cross border E-commerce [J]. Times finance, 2018 (32): 273-274

[2] Zong Luyao. Research on cross border E-commerce logistics model - Taking yiwugou as an example [J]. 
Journal of Zhejiang Wanli University, 2017 (06): 2025

[3] What changes have taken place in doing business in Yiwu [EB / OL]. (October 21, 2019) [December 31, 2019]

https://cloud.tencent.com/developer/news/509038

[4] Jun Peng. Research on ewtp's contribution to the redevelopment of real economy -- a case study of Yiwu cross border E-commerce comprehensive pilot zone. Modern industrial economy and informatization, 2019 (9): 3-4

[5] Fang Weiwei, He Xuan. Current situation and Countermeasures of Zhejiang tea export under cross border E-commerce environment [J]. Fujian tea, 2019 (02): 13-14 